\title{
CHEMICAL COMPOSITION AND ENERGY CONTENT OF DUCK FEATHERS IN THE POST-HATCHING PERIOD
}

\author{
A. HOLUB ${ }^{1}$, EMILIE PONÍŽILOVÁ ${ }^{2}$ and EVA BARANYIOVA ${ }^{3+}$ \\ ${ }^{1}$ Institute of Animal Physiology, Slovak Academy of Sciences, \\ Košice, ${ }^{2}$ Department of Veterinary Prevention, Faculty of Agronomy, \\ University of Agriculture, 61300 Brno and ${ }^{3}$ Department of Physiology, \\ University of Veterinary Science, 61242 Brno
}

Received December 20, 1987

A b s $t r$ a c $t$

H $\circ 1 \mathrm{u} \mathrm{b}$ A., Em $\mathrm{i} 1$ i e P o n i ž i $10 \mathrm{v}$ á, E v a $\mathrm{B}$ a $\mathrm{r}$ a $\mathrm{n}$ y $\mathrm{i} o \mathrm{v}$ á: Chemical Composition and Energy Content of Duck Feathers in the Post-hatching Period. Acta vet. Brno, 57, 1988 : 99-109.

Mass and chemical composition of duck feathers were investigated in 90 White Peking ducks from hatching to $56 \mathrm{~d}$ of age at weekly intervals. During this period the mass of their plumage increased 65 times while the water content of the feathers rose 324 times, i.e. nearly 5 times as much than the mass. The quantities of feather protein, fat and gross energy (GE) underwent substantially smaller increases, rising 40, 25 and 39 times, resp. The mean hydration of the feathers was low, compared with the other tissues of the body, whereas the protein concentration was high although it declined from hatching to $28 \mathrm{~d}$ of age. The fat content of the feathers was low and, except for an initial temporary rise, also decreased with age. The contribution of the feathers to total body mass was $6.2 \%$. The contributions of water, protein, fat and GE contained in the feathers to total body water, protein, fat and GE were $5.1,14.5,0.5$ and $6.1 \%$, respectively. However, they changed with age. The mass of the feathers and of their chemical components therefore grew heterogenously although differently from the observations recorded for the gastrointestina1 tract and the liver.

Ducks, age changes, fat, protein, water, gross energy, feathers.

The evidence from our previous studies on ducks showed that the intense post-hatching growth of their body mass was accompanied by rapid and heterogenous changes in chemical composition and gross energy (GE) content of the body ( $\mathrm{a}$ a $\mathrm{a} n \mathrm{y} i \mathrm{i}$ a et al. 1980) and that shifts in the protein-fat ratio of the body mass produced changes in its energy density (Ho $1 \mathrm{u} \mathrm{b}$ et al. 1987). 
In addition to the aforementioned observations we found, however, that some organs such as the gastrointestinal tract and the liver showed changes considerably different from those recorded for the body as a whole not only in terms of their mass growth but also in age-dependent changes of their chemical composition and GE accumulation and that differences in this respect existed also between the two organs ( $\mathrm{a}$ a $\mathrm{a} n \mathrm{n} i$ o $\mathbf{v}$ á et a1. 1983), obviously in association with their specific functions.

Feathers also constitute an entirely clear-cut component of the body. Their morphological aspects have been the subject of a number of studies in ducks ( $\mathrm{L} u \mathrm{c}$ a and $\mathrm{s} t \mathrm{e} t \mathrm{t} \mathrm{n} \mathrm{h}$ e $\mathrm{m}$ 1982; $\mathrm{P}$ a $1 \mathrm{~m}$ e $r$ 1982; $\mathrm{L} \ddot{\mathrm{u}} \mathrm{h} \mathrm{m}$ a $\mathrm{n} \mathrm{n}$ 1983). Little attention, however, has been paid to post-hatching changes in their chemical composition, and the few pertinent data available have not been related to the corresponding processes in the whole body of the duck and have not been quantified. These aspects are the subject of our present study.

Materials and Methods

Feathers of 90 White Peking ducks aged 1 to $56 \mathrm{~d}$ were analysed. The ducks were reared in rearing houses equipped with heaters under which the temperature was about $30^{\circ} \mathrm{C}$ and the birds were free to choose the temperature of the environment. They had free access to water and were fed a commercial starter VKCH 1 and a grower VKCH 2 ad libitum.

The measurements were carried out on groups of 10 ducks each at weekly intervals. The birds were weighed and killed by asphyxiation without being bled. The carcasses were hand-plucked and their feathers were weighed and well mixed. Samples of the feathers were then taken and dried to constant mass at 90 to $95^{\circ} \mathrm{C}$ for $24 \mathrm{~h}$. Total nitrogen and fat content of the dry matter were determined using two samples for each analysis. Total nitrogen was measured by $a$ micromethod ( $\mathrm{C} n \mathrm{w}$ a y 1957), and fat by $24 \mathrm{~h}$ petroleum-ether extraction in a Soxhlet apparatus ( $M \circ n t e m ~ u r o$ and $s t$ e $v$ e $n$ s o $n$ 1960). Water content was determined from the difference between wet mass and dry matter. Energy content of the feathers was ca1culated from their content of protein $\left(23.9 \mathrm{~kJ} \cdot \mathrm{g}^{-1}\right)$ and fat $\left(39.4 \mathrm{~kJ} . \mathrm{g}^{-1}\right)$.

Relative growth of the feather mass and its water, protein, fat and GE content were calculated according to the formula $\frac{100\left(y_{2}-y_{1}\right)}{0.5\left(y_{1}+y_{2}\right)}$ (B $r$ o $y$

1945). Increases of the water and macronutrients under study were also determined in relation to body mass. The significance of the results was evaluated by Student's t-test.

\section{Results}

The mass of the duck's feathers increased 65 times (by $135.1 \mathrm{~g}$ ) between days 1 and 56 (Tab. 1). Its mean daily increase during this 8-week period was $2.4 \mathrm{~g} \cdot \mathrm{d}^{-1}$. However, the magnitude of the rise varied from week to week, showing the highest values in the 4 th and 6 th weeks (Fig. 1). 
Table 1

Changes in feather mass, in water, protein, fat and energy in feathers of ducks in the first 8 weeks after hatching

\begin{tabular}{cccccc}
$\begin{array}{c}\text { Age } \\
\mathrm{d}\end{array}$ & $\begin{array}{c}\text { Mass } \\
\mathrm{g}\end{array}$ & $\begin{array}{c}\text { Water } \\
\mathrm{g}\end{array}$ & $\begin{array}{c}\text { Protein } \\
\mathrm{g}\end{array}$ & $\begin{array}{c}\text { Fat } \\
\mathrm{g}\end{array}$ & $\begin{array}{c}\text { Gross energy } \\
\mathrm{kJ}\end{array}$ \\
\hline 1 & $2.1 \pm 0.1$ & $0.2 \pm 0$ & $1.5 \pm 0.2$ & $0.1 \pm 0.01$ & $41 \pm 5$ \\
7 & $2.4 \pm 0.1$ & $0.2 \pm 0$ & $1.8 \pm 0.1$ & $0.1 \pm 0$ & $47 \pm 2$ \\
14 & $4.7 \pm 0.4$ & $1.1 \pm 0.1$ & $2.7 \pm 0.2$ & $0.3 \pm 0.01$ & $76 \pm 5$ \\
21 & $17.9 \pm 1.1$ & $8.1 \pm 0.7$ & $7.7 \pm 0.3$ & $0.6 \pm 0.1$ & $208 \pm 11$ \\
28 & $58.3 \pm 3.6$ & $31.9 \pm 2.4$ & $20.4 \pm 1.0$ & $1.2 \pm 0.2$ & $535 \pm 32$ \\
35 & $75.7 \pm 2.7$ & $37.1 \pm 1.5$ & $31.8 \pm 1.3$ & $1.3 \pm 0.1$ & $811 \pm 35$ \\
42 & $111.7 \pm 8.1$ & $50.5 \pm 3.2$ & $47.3 \pm 1.8$ & $2.0 \pm 0.3$ & $1209 \pm 55$ \\
49 & $122.4 \pm 3.8$ & $58.1 \pm 1.9$ & $53.7 \pm 1.7$ & $1.8 \pm 0.1$ & $1354 \pm 45$ \\
56 & $137.2 \pm 6.2$ & $64.7 \pm 0.5$ & $61.1 \pm 3.0$ & $1.7 \pm 0.2$ & $1527 \pm 80$
\end{tabular}

During the same period the water content of the feathers rose 324 times (by $64.5 \mathrm{~g}$ ), its mean daily increase being $1.1 \mathrm{~g}$ (Tab. 1). After remaining unchanged in the first week, the water content of the feathers increased 159 times between days 7 and 28 . It grew most rapidly in the 4 th week and then continued to increase at a slower rate, showing a twofold rise (Fig. 1). The mean hydration of

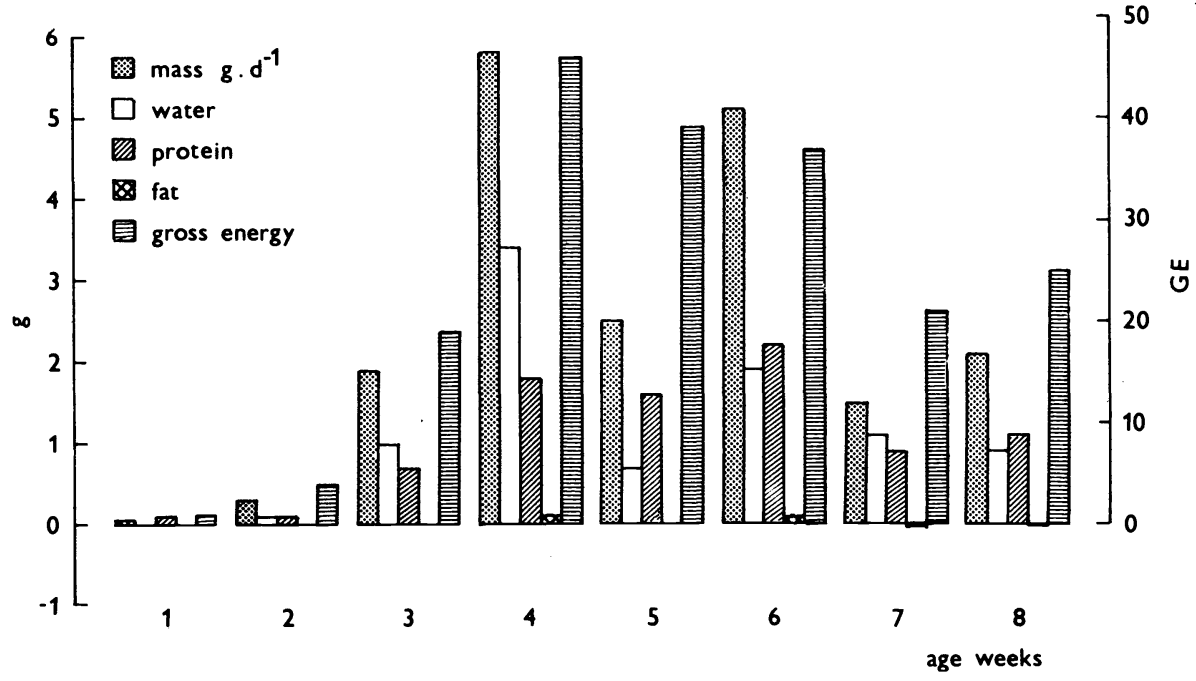

Fig. 1. Daily gains of mass, water, protein, fat and energy in feathers of ducks in the first 8 weeks after hatching 
the feathers was remarkably low, $36.7 \%$; on day 7 it was as low as $8.3 \%$. Afterwards it increased up to day 28 and oscillated about $47 \%$ in the following weeks (Fig. 2).

The protein content of the feathers increased 40 times (by $59.6 \mathrm{~g}$ ) during the first 8 post-hatching weeks. By day 21 it reached five times the original value (Tab. 1) and then increased almost 3 times during the 4th week. Another threefold rise was recorded within the following 4 weeks. In other words, the protein content of the feathers grew 4 times slower in the 5th to 8 th weeks than in the 4 th week. The mean daily increase of protein did not differ from those of the water content of the feathers (Fig. 1). However, the protein concentration of the feathers was high, averaging $50.5 \%$. It varied with age: from more than $70 \%$ on days 1 and 7 it declined to half this value by day 28 , then rose during the following week and showed a moderate upward trend till day 56 (Fig. 2).

The fat content of the feathers increased 25 times (by $1.6 \mathrm{~g}$ ) during the whole observation period. Thus it showed the least increase of all the components under study, ri-

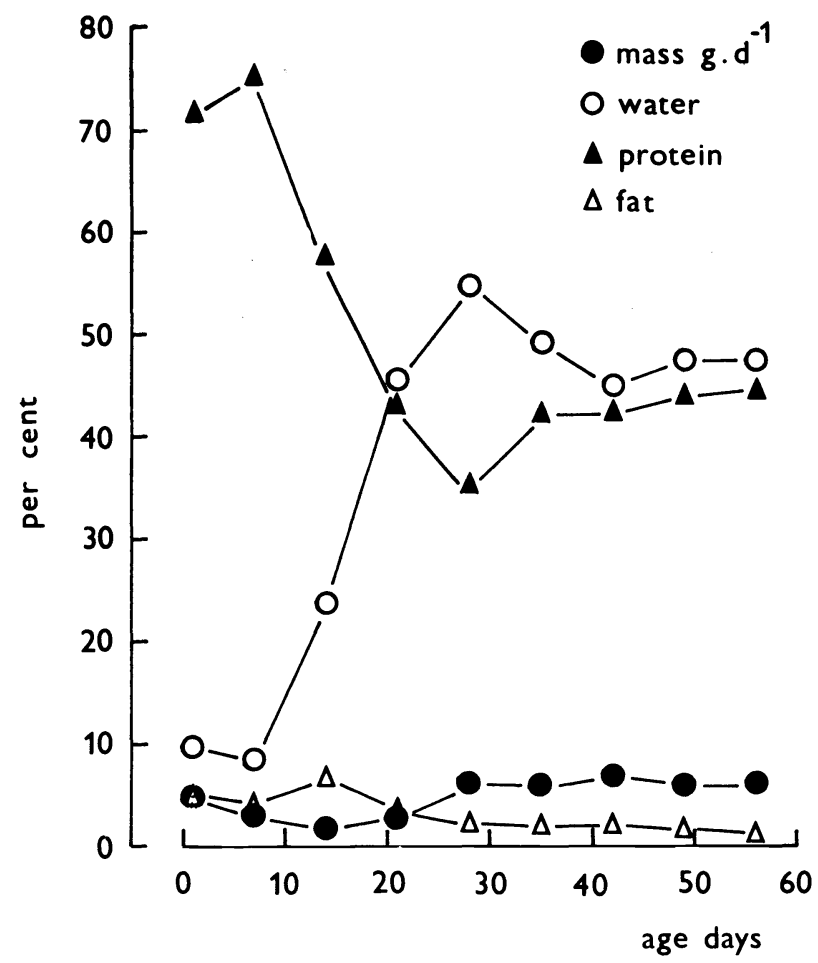

Fig. 2. Changes in proportions of feather mass to body mass and content of water, protein and fat in feathers of ducks in the first 8 weeks after hatching. 
- sing almost 40 times slowlier than the protein content; its mean daily increase was only $0.03 \mathrm{~g}$. After an upward trend in the 1st to the 6th weeks it declined in the subsequent two weeks (Tab. 1, Fig. 2). The fat concentration of the feathers was low, averaging $3.0 \%$. It varied with age: it rose till day 14 and then decreased steadily, falling eventually to less than one fifth of its peak level. Little quantitative importance of the fat appears also from the observation that, with the exception of ducks aged $14 \mathrm{~d}$, its concentration was invariably at least 10 times lower than that of protein (Fig. 2).

The amount of $\mathrm{GE}$ in the feathers rose 39 times (by $1486 \mathrm{~kJ}$ ) during the observation period, its mean daily increase being $27 \mathrm{~kJ}$ ( Tab. 1). Its accumulation rose from the 1st to the 4 th weeks, peaked in the 6 th week, at which time more than one fourth of its total deposition occurred, and then continued to rise less than one half slowlier (Fig. 1).

The relative growth of the feather components under study peaked generally in the 3 rd week. The fat content, however, peaked in the 2nd week and showed a relative decrease in the 7 th and 8 th weeks. Its relative growth exhibited a negative character (Fig. 3 ).

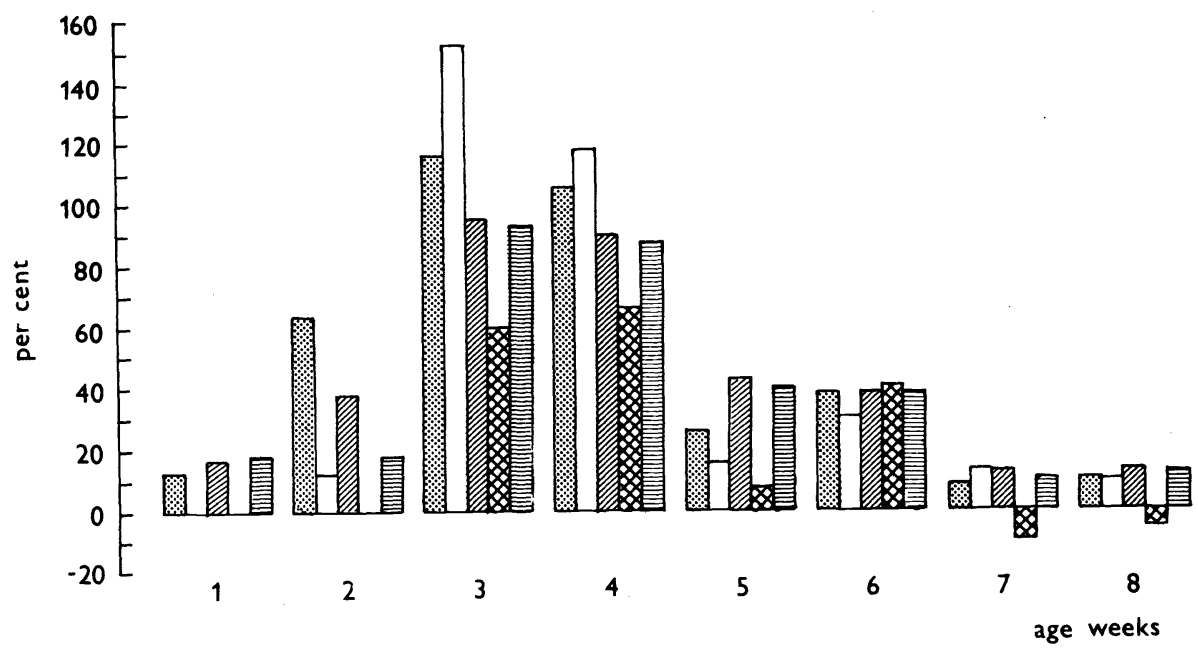

Fig. 3. Relative growth of mass, water, protein and energy in feathers of ducks in the first 8 weeks after hatching 
Expressed in relation to the feather mass, the deposition of the components under study, except fat, was highest in the 3rd week and fairly high in the 4th week. Interpreted in this way, the increases of the feather mass rose 7.6 times from the 1st to the 3rd week, continued to rise in the 4 th week, but in the 7 th week they decreased to $8 \%$ of their maximum values, equalling those observed in the 1st week. Water showed no increase in the 1st week, most of it was deposited in the 3rd and the 4 th weeks and its rise in the 8th week constituted only $8 \%$ of its peak increase. Protein showed a similar trend: its increases rose 3 times by the end of the 3rd week and then declined gradually till the 7th and 8th weeks, falling to 12 to $13 \%$ of its peak increase. Even under this relativization the age-dependent changes of the fat increases showed entirely specific features. Showing no change in the 1st week, they peaked as early as the 2nd week and then decreased so abruptly that their values in the last two weeks of the observation period were negative. Similarly, the increases in GE were highest in the third week, being 4 times higher than in the 1st week. Afterwards they declined with advancing age, falling to $11 \%$ of their peak value (Tab. 2).

Table 2

Daily relative gains in mass, water, protein, fat and energy in duck feathers in the first 8 weeks after hatching

Week Mass $\begin{array}{cccc}\text { Water } & \text { Protein } & \text { Fat } & \begin{array}{c}\text { Gross } \\ \text { energy }\end{array} \\ \mathrm{g} \cdot \mathrm{kg}^{-1} \cdot \mathrm{d}^{-1} & & \mathrm{MJ} \cdot \mathrm{kg}^{-1} \cdot \mathrm{d}^{-1}\end{array}$

$\begin{array}{rrrrrr}1 & 22 & 0 & 22 & 0 & 0.44 \\ 2 & 93 & 37 & 36 & 56 & 1.11 \\ 3 & 167 & 89 & 65 & 27 & 1.73 \\ 4 & 151 & 89 & 47 & 16 & 1.21 \\ 5 & 37 & 10 & 24 & 1 & 0.58 \\ 6 & 55 & 20 & 23 & 7 & 0.61 \\ 7 & 13 & 9 & 8 & 2 & 0.18 \\ 8 & 16 & 7 & 9 & 1 & 0.19\end{array}$




\section{Discussion}

The contribution of feathers to the total body mass of ducks (B a r a n y i o vá et al. 1983; $\mathrm{H}$ o 1 u b et al., in press) averaged $4.9 \%$ i. e. it was smaller than ( $\mathrm{Z}$ a i $\mathrm{t} s \mathrm{c} h \mathrm{e} \mathrm{k}$ 1908) or almost equal to the feather contribution reported for chickens ( $M$ o $r$ a 1977) and smaller than the corresponding findings made in turkeypoults ( $M$ o $\quad r$ a $n$ 1977) and goslings ( $M$ o $r$ a $n$ 1977; $N$ i $t \quad s$ a $n$ et al. 1981). Immediately after hatching it was close to the aforementioned average value, showed a decline on day 14 and increased fourfold by day 42 (Fig. 2). In the 7 th and 8 th weeks it was similar to the feather contribution reported for slaughter ducks ( $V$ a $v$ r o $u$ s e $k$ 1967). The age-dependent changes described in the present study are associated, no doubt, with specific morphological features of duck feathers reported previously by a number of writers ( $P$ a $1 \mathrm{~m} \mathrm{e} \mathrm{r}$ 1972; .S t r e s e m a $\mathrm{n}$ and $\mathrm{s}$ t $\mathrm{e} s \mathrm{~s}$ a $\mathrm{n}$ 1966; L ü h m a n n 1983).

The amounts and concentrations of the chemical components of duck feathers are considerably different from those recorded for the body as a whole ( $\mathrm{B}$ a $r$ a $n$ y i o va et al. 1983; $\mathrm{H} \circ \mathrm{l} \mathrm{u} \mathrm{b}$ et al., in press). Of the total water content of the body only $3.1 \%$ were found in the feathers. In the first 2 weeks the contribution of the feathers to the total water content of the body was close to the aforementioned average, then rose almost tenfold during the following 2 weeks and hovered about $5 \%$ till the end of the observation period. The finding of low feather hydration in the first week approached the observation made

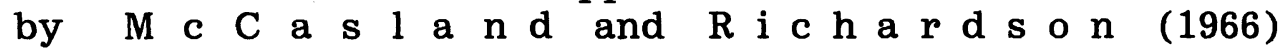
and the trend of the changes in feather hydration with advancing age was similar to the findings in goslings ( $\mathrm{N}$ i t $\mathrm{s}$ a $\mathrm{n}$ et al. 1981). Nevertheless, it was consistently lower than the total body hydration, although it showed an abrupt rise with advancing age in the first part of the observation period.

The protein component of feathers has been studied repeatedly mainly with respect to its chemical nature and amino acid composition. Feathers are relatively rich in protein ( $\mathrm{S} t$ e $t$ t e $n \mathrm{~h}$ e $\mathrm{i} \mathrm{m}$ 1972). Little difference exists in this respect between species as well as between indivi- 
dual parts of the feather ( $\mathrm{S} h \mathbf{r}$ o $\mathrm{d}$ e $r$ and $\mathrm{K}$ a $\mathrm{y}$ 1955; $\quad H$ a $r \quad r$ a $p$ and $W$ o $d s$ 1967; E s s a $r y$ and $Y \circ u n g$ 1977). The contribution of duck feathers to the total body protein in our study averaged $13.4 \%$, thus exceeding the contributions of the feathers to all the other somatic macronutrients. It was highest after hatching, declined to one third by day 14, then increased almost more than one half by day 28 and showed only a moderate upward trend afterwards. The aforementioned findings are associated with the high protein concentration of duck feathers which is three times that of the body. Its age-dependent changes were similar to those observed in goslings ( $N$ i $t$ s a $n$ et al. 1981) and the values observed by us at 8 weeks were close to the findings reported for adult domestic fowls ( $\mathrm{V}$ a $\mathrm{r}$ o u s e $\mathrm{k}$ 1967).

A quite different situation existed as regards the contribution of duck featheirs to total somatic fat. This was very low, averaging merely $1.0 \%$. It was highest after hatching and then decreased with age, first steeply and afterwards at a slower rate, thus differing diametrically from the total body fat. Also the concentration of fat in the feathers was low. After an initial rise from hatching to 2 weeks of age it declined till the end of the observation period, falling to less than one third. These age-dependent changes were different from those observed in goslings where the lipid concentration was reportedly low without any marked changes with advancing age ( $\mathrm{N}$ i t s a $\mathrm{n}$ et al. 1981).

The contribution of duck feathers to total somatic GE averaged $6.2 \%$. It was highest in the youngest birds, decreased to one third by the end of the 3rd week and increased afterwards, approaching its average value by the end of the experiment.

Also the deposition of the components of the feather mass as well as its development with advancing age were different from those recorded for the body as a whole. Thus the growth of the plumage occurred relatively late: in the 3rd, 4 th and the 6 th weeks. The accumulation of protein in the feathers was higher than in the body from the 2nd week, by which time the difference was largest, till the end of the observation period. On the other hand, the accumulati- 
on of fat in the feathers was lower than in the body, with the exception of the 2nd and the 3rd weeks. The accumulation of GE per unit feather mass was relatively higher in the 2nd to the 6th weeks and in the 8th week than its accumulation per unit body mass.

The results suggest that duck feathers grow heterogenously in the first 8 post-hatching weeks. This applies not only to their mass but also to their water, protein, fat and GE content. These phenomena are conditioned by both complicated gradual development and structuralization of feathers ( $L u$ c a $s$ 1972; $S$ t e $t$ e $n h$ e i m 1972; $\quad P$ a $1 \mathrm{~m}$ e $r$ 1972; L ü $h \mathrm{~m}$ a $n$ 1983) and maturation of their composition. The role of feathers in the early ontogeny of all precocial birds is very complex and up to now little information has been available on the nature and development of the relevant phenomena.

In our experiments the accumulation in feathers of the chemical components under study peaked at time points different from those recorded for the body as a whole. However, feathers are not the only example of this type of ontogeny. Similar observations, e.g., have been made on the gastrointestinal tract and the liver. The increases of the mass of these organs and the changes of their chemical composition with their functional development also, differed from the situation of the body as a whole ( $B$ a $r$ a $n$ y io $\mathrm{v}$ á et al. 1983) but were also different from the results reported here for duck feathers.

\section{Chemické složení a obsah energie $\mathrm{v}$ peří kachen \\ $\mathrm{v}$ postinkubačním údobí}

$\mathrm{Na}$ devadesáti kachnách plemene bílého pekingského jsme $\mathrm{v}$ týdenních intervalech zjištovali hmotnost a chemickou skladbu peří. Od vylíhnutí do věku $56 \mathrm{~d}$ se hmotnost pokryvu jejich těl zvýšila $65 \mathrm{krát}$. Množství vody $v$ něm vzrostlo $324 k r a ́ t$, tedy téměr̆ pětkrát víc než hmotnost. Bílkovin, tuků a BE (brutto energie) $v$ něm pr̆ibývalo podstatně méně a jejich množství vzrostlo 40krát, $25 \mathrm{krát}$, případně $39 \mathrm{krát}$. Průměrná hydratace peří byla ve srovnání s ostatními tkáněmi těla nízká, koncentrace proteinů naopak vysoká, i když po vylíhnutí do 28. d klesala. Obsah tuků $v$ peří byl malý a také se, až na počáteční přechodný vzestup, s věkem 
snižoval. Na somatické hmotnosti se peří průměrně podílelo $6,2 \%$. Obdobný podíl vody, bílkovin, tuků a $B E v$ peř́ byl $5.1,14.5,0.5$ a $6.1 \%$. S věkem se však měnil. I hmota peři a jeho chemických komponent tudíž rostly heterogenně, i když jinak než gastrointestinálního traktu či jater.

\section{Химический состав и содержание энергии в перьях Уток в постинкубационный период}

у 90 Уток белой пекинской породы в недельных интервалах устанавливали массу и химический состав перьев. Со дня вылупления до 56 сүток масса покрова их тела увеличилась в 65 раз. Содержание воды в нем возросло в пять раз быстрее и увеличилось в 324 раза. Количество белков, жиров и энергии (ВЭ) в перьях увеличивалось существенно меньше - в 40,25 или 39 раз. Средняя гидратация перьев по сравнению С телом была низкой и, наоборот, концентрация протеинов - высокой, хотя и после вылупливания до 28 суток она понижалась. Содержание жиров в перьях было небольшим и, за исключением первоначального переходного увеличения, оно понижалось С возрастом. Доля перьеж в массе тела составляла в среднем 6,2\%. Аналогичная доля воды, белков, жира и БЭ в перьях достигала 5,1, $14,5,0,5$ и $6,1 \%$, однако она с возрастом менялась. Следовательно, маоса перьев и их химическое компоненты возрастали гетерогенно, хотя и по-другому чем в желудочно-кишечном тракте или печени.

\section{References}

BARANYIOVÁ, E. - HOLUB, A. - PONÍ̌̆ILOVÁ, E.: Age-dependent changes in body composition of ducks in the post-incubation period. Inter. Union Physiol. Sci. XIV, XXVII Inter. Congr. Budapest, 1980, p. 312.

BARANYIOVÁ, E. - HOLUB, A. - PONǏ̌LILOVÁ, E.: Changes in the mass and chemical composition of the gastrointestinal tract and liver of ducks in the first two months after hatching. Acta vet. Brno, $\underline{52}, 1983: 39$ $-47$.

BRODY, S.: Bioenergetics and growth. New York, 1945, 1023 p. 
CONWAY, E. J.: Microdiffusion analysis and volumetric error. London, 1957, $465 \mathrm{p}$.

HARRAP, B. S. - WOODS, E. F.: Species differences in the proteins of feathers. Comp. Biochem. Physiol., 20, 1967: $449-460$.

HOLUB, A. - BARANYIOVÁ, E. - PONf́̌̌ILOVÁ, E.: Věkové změny množstvi energie $v$ těle kachen $v$ postinkubačnim údobi. Ćs. fysiol., 36, 1987: 179.

HOLUB, A. - BARANYIOVÁ, E. - PONİ̌ILOVÁ, E.: Age-dependent changes of the chemical and energy carcass composition in ducks during the first eight post-hatching weeks. Acta vet. Brno, in press.

LUCAS, A. - STETTENHEIM, P. R.: Avian anatomy integument. Part I and II. Agriculture Handbook 362, USDA 1972, Washington. In: LUtHMANN, M.: Haut und Hautderivate. In MEHNER, A. - HARTFIELD, W.: Handbuch der Gefluige1physiologie, Teil !, VEB Gustav Fischer Verlag, Jena 1983, pp. 54 100.

LÜHMANN, M.: Haut und Hautderivate. In MEHNER, A. - HARTFIELD, W.: Handbuch der Gefluigelphysiologie, Teil 1, VEB Gustav Fischer Verlag, Jena 1983, pp. 54 - 100 .

MCCASLAND, W. E. - RICHARDSON, L. R.: Methods for determining the nutritive value of feather meals. Poultry Sci., 45, 1966: 1231 - 1236.

MONTEMURRO, D. G. - STEVENSON, A. F.: Survival and body composition of normal and hypothalamic obese rats in acute starvation. Amer. J. Physiol., 198, 1960: 757 - 761 .

MORAN Jr., E. T.: Growth and meat yield in poultry. In: Growth and poultry meat production, Ed. BOORMAN, K. N. - WILSON, B. J.: Edinburgh, 1977, 145 - 173.

NITSAN, Z. - DVORIN, A. - NIR, I.: Composition and amino acid content of carcass, skin and feathers of the growing gosling. Brit. Poult. Sci., 22, 1981: $79-84$.

PALMER, R. S.: Patterns of molting. In: Avian Biology, Vol. II, Ed. FARNER, D. S. - KING, J. R. - PARKES, K. C. Academic Press, New York, London, 1972, pp. 2 - 63 .

SCHROEDER, W. A. - KAY, L. M.: The amino acid composition of certain morphologically distinct parts of white turkey feathers and of goose feather barbs and goose down. J. Amer. Chem. Soc., 77, 1955: 3901 - 3908.

STETTENHEIM, P.: The integumentum of birds. In: Avian Biology, Vol. II, Ed. FARNER, D. S. - KING, J. R. - PARKES, K. C. Academic Press, New York, London 1972, pp. 2 - 63.

STRESEMANN, E. - STRESEMANN, V.: Die Mauser der Vögel. J. Ornithol., 107 (Sonderheft), 1966; 445 p.

VAVROUŠEK, J.: Zpracováni peři. In: ŠIMA, F. et al.: Zpracováni drůbežich výrobků. SZN Praha, 1971, pp. 259 - 315.

ZAITSCHEK, A.: Über die Verteilung des Lebendsgewichtes auf die Organe beim Huhn. Landw. Jahrb., 37, 1908: 150 - 171.

\footnotetext{
+Requests for reprints should be addressed to Dr. Eva Baranyiová, Department of Physiology, University of Veterinary Science, CS-612 42 Brno, Czechoslovakia
} 